\title{
Immunosenescence: implications for vaccination programs in the elderly
}

\author{
This article was published in the following Dove Press journal: \\ Vaccine: Development and Therapy \\ 6 August 2015 \\ Number of times this article has been viewed
}

\author{
Dessi Loukov ${ }^{1,2, *}$ \\ Avee Naidoo 1,2,* \\ Dawn ME Bowdish ${ }^{1,2}$ \\ 'Department of Pathology and \\ Molecular Medicine, McMaster \\ Immunology Research Centre, \\ McMaster University, Hamilton, ON, \\ Canada; ${ }^{2}$ Department of Pathology \\ and Molecular Medicine, Institute \\ for Infectious Diseases Research, \\ McMaster University, Hamilton, ON, \\ Canada \\ *These authors contributed equally to \\ this work
}

\begin{abstract}
Worldwide, infectious disease is responsible for much of the morbidity and mortality in the elderly. As the number of individuals over the age of 65 increases, the economic and social costs of treating these infections will become a major challenge. Vaccination is the most effective and least costly preventative measure in our arsenal; however, vaccines that are effective in children and young adults are often ineffective in older adults. This is a result of the deterioration in immune function that occurs with age, referred to as immunosenescence. Age-associated changes in leukocyte phenotype and function impair primary vaccine responses and weaken long-lasting memory responses. In this review, we discuss current vaccination approaches in the elderly and strategies to improve responsiveness in older adults, which include increasing vaccine immunogenicity and overcoming the fundamental immune defects that prevent optimal immune responses.
\end{abstract}

Keywords: immunosenescence, vaccination, elderly, influenza, pneumonia, zoster

\section{Introduction}

By the year 2050, more than $25 \%$ of the world's population will be 65 years of age or older. ${ }^{1}$ Susceptibility to infectious disease increases with age and in addition to other age-related health issues, poses an enormous challenge to health care systems in the developed world. In the US, pneumonia and influenza were the eighth leading causes of death in 2005, and the elderly (aged $\geq 65$ years) accounted for an estimated $90 \%$ of these deaths. ${ }^{2-4}$ Combined, these diseases cost the US economy $\$ 40.2$ billion due to direct and indirect health care expenditures and mortality-related losses in productivity. ${ }^{5}$ The economic and social costs of infection include acute treatment and long-term health outcomes. For example, having pneumonia in midlife to late life accelerates development of dementia, respiratory, and cardiac conditions, as well as fall-related injuries that require hospitalization. Consequently, calculations on the costs of acquiring pneumonia in midlife to late life must include the costs of long-term consequences of infection..$^{6-8}$

Infectious diseases account for roughly $20 \%$ of hospitalizations in the elderly. ${ }^{9}$ Vaccines are the most successful tools we have in preventing infectious disease. Four vaccines are currently recommended for use in the elderly: the seasonal influenza vaccine, the pneumococcal vaccine, the tetanus-diphtheria-pertussis vaccine, and the vaccine to prevent shingles, which is caused by reactivation of Herpes zoster virus (Table 1). ${ }^{10}$ Despite the importance of preventing these infections and relatively high vaccination rates, protection is still suboptimal due to decreasing immune function with age. ${ }^{11}$ 
Table I Current vaccine recommendations in the elderly

\begin{tabular}{|c|c|c|c|c|}
\hline Vaccine & Type & Adjuvant & Site & Schedule \\
\hline $\begin{array}{l}\text { Diphtheria-tetanus } \\
\text { acellular pertussis } \\
\text { (DTAP) }\end{array}$ & Subunit (Adacel ${ }^{\circledR}$, Boostrix ${ }^{\circledR}$ ) & Alum & IM & $\begin{array}{l}\text { One dose administered if patient has not received } \\
\text { in adulthood (age }>18 \text { years) and boost every } \\
10 \text { years. Adults not previously vaccinated receive } \\
\text { at least three doses at } 0 \text { (DTAP), } 8 \text { weeks (DT), } \\
\text { and } 6-12 \text { months (DT). }\end{array}$ \\
\hline Herpes zoster & Attenuated $\left(\right.$ Zostavax $\left.^{\circledR}\right)$ & $\mathrm{N} / \mathrm{A}$ & SC & $\begin{array}{l}\text { One dose administered regardless of prior history } \\
\text { of shingles. }\end{array}$ \\
\hline \multirow[t]{2}{*}{ Influenza } & $\begin{array}{l}\text { Inactivated split virus (Fluviral }{ }^{\circledR} \text {, } \\
\text { Vaxigri }^{\circledR}, \text { Fluzone }^{\circledast}, \text { Agriflu }^{\circledR}, \\
\text { Influvac }^{\circledR}, \text { Intanza }{ }^{\circledR} \text { ) }\end{array}$ & N/A & $\begin{array}{l}\text { IM or } \\
\text { ID }\left(\text { Intanza }{ }^{\circledR}\right)\end{array}$ & $\begin{array}{l}\text { One high dose trivalent vaccine administered every } \\
\text { flu season. }\end{array}$ \\
\hline & Subunit $\left(\right.$ Fluad $\left.^{\circledR}\right)$ & MF59 & IM & \\
\hline Pneumococcal & $\begin{array}{l}\text { Conjugate }\left(\text { Prevnar }^{\circledR} \mid 3\right) \\
\text { Polysaccharide subunit } \\
\left(\text { Pneumovax }^{\circledR} 23, \text { Pneumo 23 }{ }^{\circledR}\right)\end{array}$ & $\begin{array}{l}\text { Alum } \\
\text { N/A }\end{array}$ & $\begin{array}{l}\text { IM } \\
\text { IM/SC }\end{array}$ & $\begin{array}{l}\text { Vaccine-naïe individuals receive one dose PCVI3, } \\
\text { followed by one dose PPSV } 236-12 \text { months later. } \\
\text { Individuals that previously received PPSV } 23 \text { at age } \\
\geq 65 \text { years, receive one dose PCVI } 3 \geq 1 \text { year later. } \\
\text { Individuals that received PPSV } 23 \text { before age } 65 \text { years } \\
\text { and now are aged } \geq 65 \text { years receive one dose } \\
\text { PCVI } 3 \text { and one dose PPSV23 6-12 months later. }\end{array}$ \\
\hline
\end{tabular}

Abbreviations: N/A, not applicable; IM, intramuscular; SC, subcutaneous; ID, intradermal; DT, diphtheria-tetanus; PCV, pneumococcal conjugate vaccine; PPSV23, 23-valent pneumococcal polysaccharide vaccine; PCVI3, I3-valent pneumococcal conjugate vaccine.

Respiratory tract infections, particularly influenza and pneumonia, account for the majority of hospitalizations due to infectious disease in the elderly. Due to widespread use and careful monitoring of influenza and pneumococcal vaccines, data on the efficacy of these vaccines are well understood. Despite reasonably high vaccination rates in the elderly (61.3\% influenza, 59.9\% pneumococcal), influenza and pneumonia infections are still associated with serious adverse events leading to hospitalization, debilitating complications, and mortality in the elderly. ${ }^{9,12,13}$

Seasonal influenza causes moderate illness in healthy adults that is generally resolved within 2 weeks; however, children, those with comorbidities, and the elderly are at increased risk of complications (ie, pneumonia, bronchitis, and/or sinus infection) that may result in hospitalization and mortality. Consequently, in many countries influenza vaccination efforts focus on children (aged 6 months-17 years) and the elderly (aged $\geq 65$ years). Vaccination rates are as high as $56.6 \%$ in children and $61.3 \%$ in the elderly, while coverage in adults (aged 1-64 years) is $35.7 \% .{ }^{13}$ Even though rates of coverage may be the same in the young and old, protection rates are very different. Studies measuring vaccine efficacy monitor "influenza-like illness", which is used for a proxy of influenza infection without virology testing to confirm the infection. In studies that monitor the effectiveness of the trivalent inactivated vaccines, there were marked differences in protection from influenza-like illnesses between these two age groups. For example, a recent meta-analysis suggests that $58 \%$ of vaccinated children (aged $<16$ years) were protected from influenza-like illness. ${ }^{14}$ In a large meta-analysis of influenza vaccination in the nursing home or communitydwelling elderly, there was no significant protection from influenza despite the use of antigen-matched vaccines. ${ }^{15}$ Age-related changes in immunity are believed to contribute to the disparity in protective efficacy of trivalent inactivated influenza vaccine (TIV) in these two populations. ${ }^{15}$

Bacterial pneumonia is a common consequence of seasonal and pandemic influenza infection, and is a major cause of morbidity and mortality in the elderly. ${ }^{16}$ To prevent community-acquired pneumonia, nursing home-acquired pneumonia, and ventilator-acquired pneumonia, vaccines against the major causative agent, Streptococcus pneumoniae, have been developed. In the elderly, S. pneumoniae generally causes pneumonia, but more rarely, can cause invasive pneumococcal disease (IPD) (eg, meningitis or septicemia). The most recent Cochrane meta-analysis of the efficacy of the 23-valent pneumococcal polysaccharide vaccine (PPSV23) vaccine demonstrated that there was significant protection from IPD (odds ratio [OR], 0.26; 95\% confidence interval [CI], 0.15-0.46), but there was no evidence for protection against pneumonia (including community-acquired pneumonia, nursing home-acquired pneumonia, and ventilatoracquired pneumonia) in the elderly. ${ }^{17}$ With few exceptions, other studies have confirmed that there is some protection against IPD, but not pneumonia, in the elderly. ${ }^{18-21}$ Current vaccines are clearly not sufficient to protect the elderly from the infectious diseases that they are most susceptible to, and this is likely due to waning immune function. ${ }^{22}$ With age, there 
is an increase in inflammatory mediators in serum and tissues, accompanied by phenotypic and functional changes to leukocytes, which affect all elements of the immune response necessary to mount a response to vaccination (Figure 1). This review will focus on age-related immune changes relevant to the vaccine response and will provide commentary, based on current data, as to how vaccines can be tailored to provide increased protection in the elderly.

\section{Influence of immunosenescence on vaccine-elicited immune responses Anatomy of a vaccine response}

\section{Vaccine effector responses}

Vaccines prime the adaptive immune system to produce a rapid, robust, and protective immune response upon subsequent exposure to an infectious agent. This "memory" response is mediated by antigen-specific lymphocytes (ie, B and T cells). Antigen-specific antibodies produced by $B$ cells bind and neutralize viruses and extracellular bacteria and also mediate their uptake and clearance by macrophages and neutrophils. T cell-mediated responses act to directly or indirectly kill infected cells. Although vaccine effector mechanisms are executed by the adaptive immune system, their generation depends on the innate immune response.

Antigen uptake and antigen-presenting cell activation Antigen-presenting cells (APCs), primarily dendritic cells (DCs), ingest the vaccine antigen at the site of administration, become activated, and later present the antigen to B and $\mathrm{T}$ cells. Activation of APCs is required to initiate production of pro-inflammatory cytokines that upregulate homing receptors, which are required for the DC to migrate to the draining lymph node and present antigens to T cells. An inflammatory response is also required to increase co-stimulatory molecule expression that is needed to activate $\mathrm{T}$ and $\mathrm{B}$ cells. The degree of APC activation is highly dependent on the type of vaccine that is administered (Table 2 ). ${ }^{23-25}$ For example, live attenuated vaccines are potent immune activators because they are briefly able to replicate, leading to increased and prolonged exposure to antigens and immunostimulatory viral components such as nucleic acids. In contrast, immune responses to purified antigens (ie, protein, polysaccharide, glycoconjugate, and

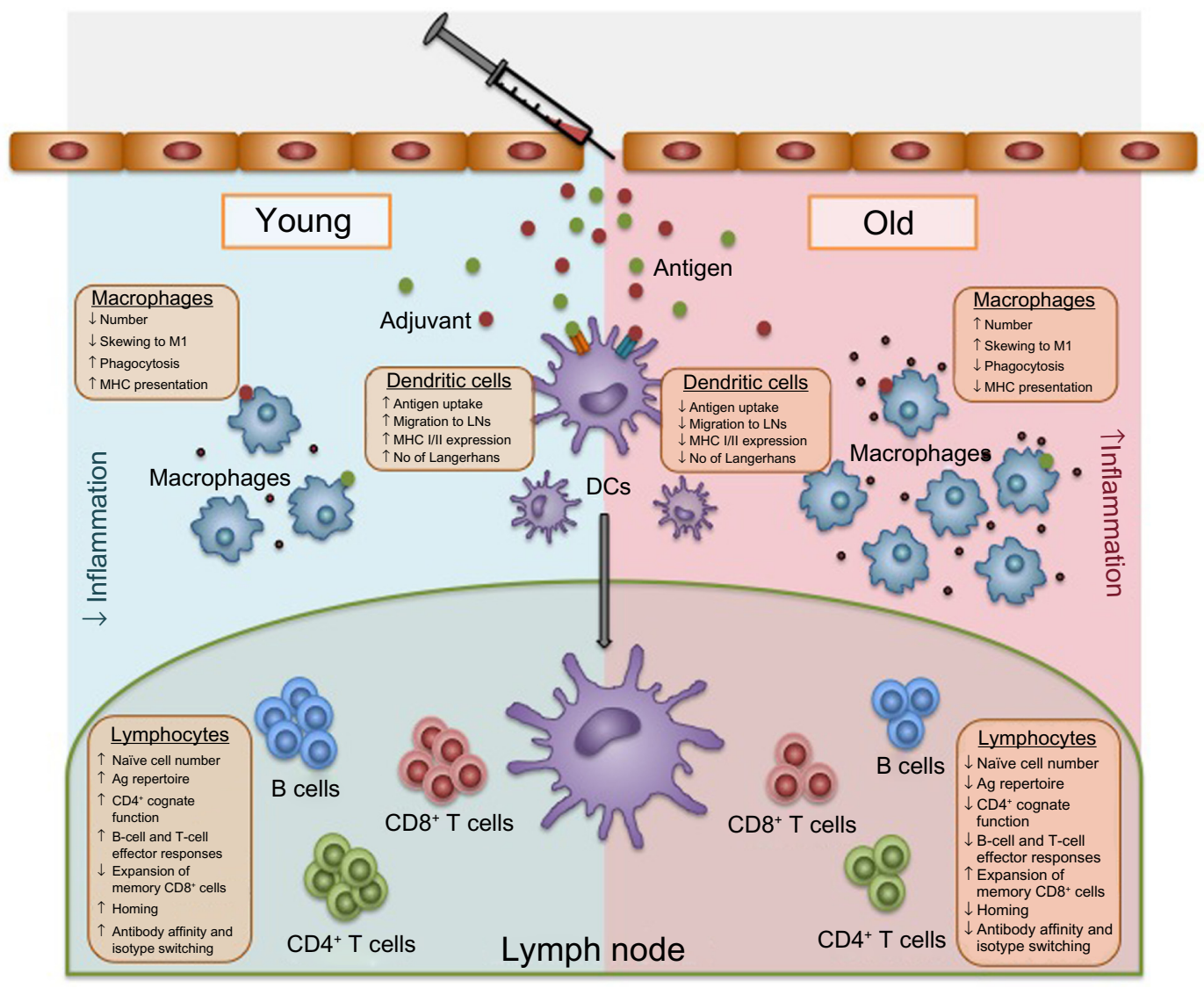

Figure I All elements of the immune response necessary to mount a response to vaccination.

Abbreviations: MHC, major histocompatibility complex; No, number; LNs, lymph nodes; DCs, dendritic cells. 
Table 2 Vaccine types and immune responses elicited

\begin{tabular}{|c|c|c|}
\hline Vaccine type & Components & Response elicited \\
\hline \multicolumn{3}{|l|}{ Non-live vaccines } \\
\hline Subunit & $\begin{array}{l}\text { Purified pathogen } \\
\text { proteins, isolated } \\
\text { toxins } \\
\text { Surface } \\
\text { polysaccharides } \\
\text { isolated from } \\
\text { bacterial capsule }\end{array}$ & $\begin{array}{l}\text { T cell-dependent } \\
\text { antibody production } \\
\text { Minimal CTL responses } \\
\text { T cell-independent } \\
\text { antibody production } \\
\text { Minimal isotype class } \\
\text { switching } \\
\text { Poor recall response } \\
\text { following booster }\end{array}$ \\
\hline $\begin{array}{l}\text { Polysaccharide } \\
\text { conjugate }\end{array}$ & $\begin{array}{l}\text { Covalently attached } \\
\text { polysaccharide to } \\
\text { carrier protein }\end{array}$ & $\begin{array}{l}\text { T cell-dependent } \\
\text { antibody production } \\
\text { Minimal CTL responses }\end{array}$ \\
\hline Inactivated & $\begin{array}{l}\text { Whole pathogens } \\
\text { inactivated by } \\
\text { chemical or physical } \\
\text { treatment }\end{array}$ & $\begin{array}{l}\text { Antibody production } \\
\text { No CTL responses } \\
\text { Poor memory responses }\end{array}$ \\
\hline \multicolumn{3}{|l|}{ Live vaccines } \\
\hline Live, attenuated & $\begin{array}{l}\text { Replicative } \\
\text { pathogens with } \\
\text { reduced virulence } \\
\text { Retains some } \\
\text { pathogenicity }\end{array}$ & $\begin{array}{l}\text { T cell-dependent } \\
\text { antibody production } \\
\text { Long-lasting circulating } \\
\text { antibodies } \\
\text { Effective CTL responses } \\
\text { Good memory responses }\end{array}$ \\
\hline Live & $\begin{array}{l}\text { Low doses of actual } \\
\text { pathogen }\end{array}$ & $\begin{array}{l}\text { Most effective protection } \\
\text { T cell-dependent } \\
\text { antibody production } \\
\text { Long-lasting circulating } \\
\text { antibodies } \\
\text { Effective CTL responses } \\
\text { Good memory responses }\end{array}$ \\
\hline
\end{tabular}

Abbreviation: CTL, cytotoxic T lymphocyte.

inactivated microbes) are more fleeting as they are rapidly cleared from the vaccination site. Purified protein (eg, viral capsid proteins) or carbohydrate (eg, the polysaccharide capsule of S. pneumoniae) antigens are poorly immunogenic on their own, except in very high doses. Adjuvants enhance immunogenicity of these proteins and carbohydrates by enhancing antigen presentation or co-stimulation by the APCs. ${ }^{26}$ Adjuvants such as alum and oil-in-water emulsions (ie, MF59) trap antigens at the site of injection, creating a depot from which antigen is slowly released, providing longer antigen exposure and increasing recruitment of APCs. In unadjuvanted vaccines, antigen doses are increased considerably (ie, from $3.75 \mu \mathrm{g}$ to $15 \mu \mathrm{g}$ for influenza vaccine). ${ }^{27}$

\section{Protein subunit, conjugate, and} inactivated vaccine responses

As mentioned in the "Antigen uptake and antigen-presenting cell activation" section, APCs play a crucial role in linking the innate and adaptive arms of immunity, because they present processed antigen to $\mathrm{T}$ cells. ${ }^{28}$ Antigens are presented to $\mathrm{T}$ cells in the context of major histocompatibility complex (MHC) molecules (human leukocyte antigen in humans). Proteins and inert particles are taken up and processed into peptides for presentation on MHC class II. Presentation by APCs activates $\mathrm{CD} 4^{+} \mathrm{T}$ cells in secondary lymphoid tissue. ${ }^{29} \mathrm{CD} 4^{+} \mathrm{T}$ cells support the differentiation of $\mathrm{B}$ cells, $\mathrm{CD} 8^{+} \mathrm{T}$ cells, and macrophages that act to directly eliminate microbes. Naïve B cells can also take up antigen, which when presented in the context of co-stimulation from activated APCs and $\mathrm{CD}^{+} \mathrm{T}$ cells, leads to their differentiation into low-affinity IgM-producing plasma cells. B cells also present antigen-to-antigen-specific $\mathrm{CD} 4^{+}$ $\mathrm{T}$ cells, which provide cognate help through co-stimulation. $\mathrm{CD}^{+} \mathrm{T}$ cells help drive immunoglobulin class switching and affinity maturation, and result in plasma cells that produce high-affinity, antigen-specific antibodies. This T celldependent antibody response is slow and requires 10-14 days; however, it generates long-lasting, high-affinity antibodies and a memory B cell response. ${ }^{30}$

\section{Live attenuated vaccines}

By infecting and replicating in host cells, antigens from live attenuated viruses will be presented on MHC class I molecules to $\mathrm{CD}^{+} \mathrm{T}$ cells. Also referred to as cytotoxic $\mathrm{T}$ lymphocytes, $\mathrm{CD} 8^{+} \mathrm{T}$ cells kill infected cells by destroying them with mediators such as perforins and granzymes. Peptide antigens from live attenuated vaccines may also be presented on MHC class II and may elicit $\mathrm{CD}^{+} \mathrm{T}$ cell and antibody production from B cells. ${ }^{30}$

\section{Polysaccharide vaccines}

Polysaccharide antigens act through $\mathrm{T}$ cell-independent pathways to generate an antibody response. Polysaccharides interact with marginal zone B cells in secondary lymphoid tissues. The polysaccharide cross-links the B cell receptor, causing activation and differentiation into a plasma cell-producing IgM. Some isotype switching from IgM to intermediate-affinity IgG occurs. In contrast to the $\mathrm{T}$ celldependent response, this response is rapid, transient (1 week long), produces low-affinity antibodies, and does not result in a memory response. In order to circumvent this short-lived response, polysaccharide vaccines are conjugated to immunogenic carrier proteins (ie, tetanus and diphtheria toxoids) to elicit a $\mathrm{T}$ cell-dependent $\mathrm{B}$ cell response. ${ }^{31,32}$

\section{Memory responses}

The generation of memory responses is the ultimate goal of vaccination. Following the primary response to $T$ cell-dependent antigens, antigen-specific $B$ and $T$ cell numbers decline. The efficacy of a memory response is dictated by 
the primary immune response and the number of exposures to antigen. The primary immune response is highly dependent on antigen dose and persistence, which is why live attenuated vaccines generate long-lasting memory responses. Most other inactivated and subunit vaccines require booster vaccinations. A small fraction of B cells, now memory B cells, will migrate to long-term survival niches such as the bone marrow where they continue to undergo affinity maturation for 4-6 months, increasing their antibody affinity. ${ }^{33}$ Thus, boosters are generally administered 4-6 months following primary responses, allowing time for the generation of memory $\mathrm{B}$ cells. Antigen-specific effector T cells are short-lived and also decline following primary response. Those that persist can become either an effector memory $\mathrm{T}$ cell $\left(\mathrm{T}_{\mathrm{em}}\right)$ or a central memory $\mathrm{T}$ cell $\left(\mathrm{T}_{\mathrm{cm}}\right) . \mathrm{T}_{\mathrm{em}} \mathrm{s}$ migrate through non-lymphoid organs, patrolling tissues for their antigens, and have high cytotoxic activity once reactivated. Conversely, $\mathrm{T}_{\mathrm{cm}} \mathrm{s}$ traffic through lymphoid organs and have high proliferative capacity, generating a large surge of effector cells. ${ }^{34} \mathrm{The}_{\mathrm{em}}$ response relies on the magnitude of T cell expansion following primary vaccination, which is increased with higher antigen load and persistence. ${ }^{30}$ Increased numbers of $\mathrm{T}_{\mathrm{em}} \mathrm{s}$ will result in more $\mathrm{T}_{\mathrm{em}} \mathrm{s}$ following the contraction phase of the $\mathrm{T}$ cell response.

Reactivation of memory cells can occur through natural colonization by microbes with cross-reacting epitopes, infection, or by booster immunizations. This leads to activation of memory $\mathrm{B}$ cells, which do not require cognate $\mathrm{CD}^{+}$ $\mathrm{T}$ cell help, and leads to rapid proliferation and secretion of high-affinity antibodies. Memory $\mathrm{CD}^{+}$and $\mathrm{CD}^{+} \mathrm{T}$ cells are also activated by cognate antigen and do not require costimulation. Generally, booster immunizations include higher antigen content than primary immunizations to increase the activation and proliferation of memory B cells. Upon multiple or prolonged exposures to antigens, activated memory B cells undergo further affinity maturation and produce higher affinity antibodies. ${ }^{30}$

\section{Changes in vaccine responses with age}

Both humoral and cellular immune responses to primary immunization and boosters decrease with age. ${ }^{35-38}$ These antibody- and $\mathrm{T}$ cell-mediated specific immune responses depend on priming by competent APCs, such as DCs and macrophages. APCs from aged individuals, however, are less able to take up antigens by the process of micropinocytosis, have decreased capacity to present antigens due to decreased MHC class I and MHC class II expression, ${ }^{39-43}$ and are less responsive to the chemokine CCL19, which is required for migration to the lymph nodes. ${ }^{44}$ The impairment of DC migration is due to both intrinsic age-associated defects in the DCs themselves, in addition to the presence of changes in cytokine levels in the aging microenvironment. ${ }^{44}$ Human DCs also have decreased expression of the co-stimulatory molecules, CD86 and CD80, which impairs T cell activation. ${ }^{44-47}$

With age, the number of naïve $B$ and $T$ cells produced by the bone marrow decreases, ${ }^{48}$ due in part to changes in the aging microenvironment. ${ }^{49}$ This results in a decreased ability to respond to new infections or vaccinations, ${ }^{50}$ although a study shows that in some viral infections (eg, West Nile virus) the elderly are capable of mounting a de novo response. ${ }^{51}$ Elevated levels of tumor necrosis factor (TNF) in the bone marrow decrease B cell lymphopoiesis and plasma cell survival. ${ }^{52}$ Antibodies produced in aged individuals tend to be of lower affinity due to reduced isotype switching and somatic hypermutation, and consequently their neutralizing or opsonizing functions are decreased. This is due to impaired $\mathrm{CD}^{+} \mathrm{T}$ cell help because of decreased germinal center formation in peripheral lymph nodes, which are necessary for an efficient, high-affinity humoral response. ${ }^{53-55}$ The $\mathrm{T}$ cell compartment also undergoes significant changes with age. Levels of IL-7, a cytokine that promotes development of T cells in the thymus and thymic involution, result in decreased peripheral naïve $\mathrm{T}$ cells $\left(\mathrm{CD} 45 \mathrm{RA}^{+} \mathrm{CD} 28^{+}\right){ }^{56,57}$ Aged naïve $\mathrm{T}$ cells are increasingly difficult to prime. ${ }^{58}$ Naïve $\mathrm{CD} 4^{+} \mathrm{T}$ cells from aged animals show decreased effector cytokine production (ie, IL-2), less clonal expansion, and decreased expression of activation markers (CD25, CD62L, and CD154) following primary antigen presentation by APCs. ${ }^{58,59}$ $\mathrm{CD}^{+} \mathrm{T}$ cell function is impaired with age, leading to weaker humoral and $\mathrm{CD} 8^{+} \mathrm{T}$ cell responses, which can contribute to vaccine failure in the elderly. ${ }^{53}$

Although memory cells are generated from naïve T cells in the elderly and show persistence in vivo, they exhibit impaired cytokine secretion and proliferation upon recall responses. ${ }^{60}$ Memory $\mathrm{CD}^{+} \mathrm{T}$ cells generated in young mice were shown to be functional in their host as they aged, while those generated in aged mice were non-functional. ${ }^{60}$ Moreover, young $\mathrm{CD}^{+} \mathrm{T}$ cells transferred to aged, immunized hosts maintained their capacity to induce a robust humoral response. ${ }^{59}$ Similar results were also shown with old $\mathrm{CD} 8^{+} \mathrm{T}$ cells, ${ }^{61}$ suggesting that changes to $\mathrm{T}$ cell function are intrinsic and dependent on the age of the host. This implies age at primary vaccination is a more important determinant of proper memory $\mathrm{T}$ cell function, rather than age at recall response. A recent study demonstrated that following primary exposure to West Nile virus, antigen-specific $\mathrm{CD}^{+} \mathrm{T}$ cells from elderly donors maintained production of antiviral cytokines, granzyme B, and perforin for up to 2 years. These results were comparable to younger adults. ${ }^{51}$ In contrast, older primates have weak antiviral 
$\mathrm{CD}^{+} \mathrm{T}$ cell responses to West Nile virus. ${ }^{62}$ However instead of using live virus, the Lelic et al study ${ }^{51}$ employed synthetic immunodominant peptides for re-stimulation that did not require further processing by APCs. Since antigen presentation is also compromised with age, employing peptide-based booster vaccines may be an alternative strategy to elicit a strong $\mathrm{CD}^{+} \mathrm{T}$ cell response in the elderly.

Even when the elderly mount a robust primary immune response, they may be less able to maintain antigen-specific memory cells. Chronic infections (ie, Herpes simplex virus, cytomegalovirus [CMV], and Epstein Barr virus) provide constant antigenic stimulation and lead to an expansion of terminally differentiated effector $\mathrm{CD}^{+} \mathrm{T}$ cells, reducing space in the $\mathrm{T}$ cell repertoire for other antigen-specific $\mathrm{T}$ cells, including those generated by vaccination. This has been demonstrated in the elderly who are chronically infected with CMV and whose peripheral memory $\mathrm{T}$ cell repertoires are dominated by CMV-specific effector T cells. This prevents the expansion of $\mathrm{T}$ cell clones with other specificities due to limited space in the $\mathrm{T}$ cell repertoire. Not only do CMV effector cells impair the response to co-resident Epstein Barr virus infection, ${ }^{63}$ but their increased numbers in the elderly have been correlated with decreased humoral responses following influenza vaccination. ${ }^{64,65}$ Additionally, CMV memory $\mathrm{T}$ cells produce increased levels of interferon gamma (IFN- $\gamma$ ), contributing to chronic age-associated inflammation. ${ }^{66,67}$

As we age, levels of pro-inflammatory cytokines in the circulation and tissues increase. This state of chronic, low-grade, systemic inflammation is often called "inflamm-aging". ${ }^{22}$ Although it is unclear why we become more inflamed with age, epidemiological data clearly demonstrate that the effects of age-associated inflammation are far-reaching. Age-associated inflammation seems to correlate with poor health in general, as higher than average levels of ageassociated inflammation correlate with the development of chronic inflammatory disease, frailty, and general ill health. ${ }^{68,69}$ Having higher than age-average levels of these cytokines increases susceptibility to infectious disease (eg, pulmonary pneumonia and influenza) ${ }^{70,71}$ and is predictive of decreased vaccine responsiveness. ${ }^{67}$

Vaccine responsiveness does not decrease in a linear fashion with age, and often correlates more strongly with general health. Conversely, a robust vaccine response is a predictor of immune competence and good health. ${ }^{72}$ In general, vaccine responsiveness correlates with frailty, defined as declining physical and mental function and reduced ability to resist environmental stressors. ${ }^{73,74}$ Frailty is strongly associated with inflamm-aging, likely because immune competence is a mandatory requirement for overall health (eg, TNF, C-reactive protein [CRP], and IL-6). ${ }^{75-79}$ In order to disentangle which elements of decreasing vaccine responsiveness are due to age rather than ill health, protocols have been developed to study only the healthiest older adults. The most commonly used is the SENIEUR protocol, ${ }^{80}$ which excludes anyone taking immune-modulating medication, those with chronic disease (ie, atherosclerosis, Crohn's disease, etc), or abnormal values for common clinical measures (ie, leukocyte counts, urea, and glucose). Although this excludes the vast majority of older adults, it allows comparisons of the most immune-competent ("SENIEURs") to those with the normal allotment of ageassociated changes in health ("non-SENIEURs"). A recent study evaluated influenza vaccine responses in the elderly during an epidemic season. Serum levels of IL-6 were measured before and 1 and 6 months after immunization. ${ }^{67}$ The healthy elderly, or SENIEURs, had consistently low levels of IL-6 throughout the study, while the frail elderly, or nonSENIEURs, had significantly higher levels. The serum IL-6 levels correlated inversely with a protective vaccine response, measured by anti-hemagglutinin (HA) titer. The SENIEURs, who had low levels of IL-6, responded following their first immunization, while the non-SENIEURs with high IL-6 levels were permanent non-responders. ${ }^{67}$

These findings emphasize the importance of assessing immune competence in the target vaccine population prior to immunization. Currently, the elderly are uniformly treated with regard to vaccination. By developing an indicative marker of immune competence and vaccine non-response (ie, elevated serum cytokines), we can more efficiently administer vaccines to those with a higher likelihood of responding, while pursuing alternative vaccination strategies in the remaining at-risk population.

\section{Adapting vaccination for the aging immune system}

\section{Increasing dose}

In pre-clinical studies, data suggest that increasing the dose of HA antigen in influenza vaccines would increase antibody titers in the elderly. ${ }^{81} \mathrm{~A}$ double-blinded, randomized, multicenter trial comparing the standard dose $(15 \mu \mathrm{g}$ HA per strain) to a high dose $\left(60 \mu\right.$ g per strain) of Fluzone ${ }^{\circledR}$ (Sanofi, Bridgewater, NJ, USA) was conducted in adults 65 years or older. The group receiving the high dose had antibody levels that were $12 \%-25 \%$ higher than the standard dose group for the three viral strains $\left(\mathrm{H} 1 \mathrm{~N} 1, \mathrm{H} 3 \mathrm{~N} 2\right.$, and B). ${ }^{82}$ In another study where trivalent split influenza vaccine (Sanofi) dose was doubled (from $15 \mu \mathrm{g}$ to $30 \mu \mathrm{g}$ ) in the frail elderly, antibody 
responses were also increased. ${ }^{83}$ Although increasing HA antigen dose induces more antibodies, which are presumed to be a correlate of protection, studies that definitively demonstrate protection against infection are lacking. ${ }^{14}$ The relationship between increased dose and increased immunogenicity does not appear to be universal to all vaccines. Increasing the amount of live attenuated Varicella zoster virus $(1 \times, 2.7 \times$, and $13 \times$ standard dose) in the elderly did not increase the vaccine-specific antibody or cell-mediated response. ${ }^{84}$ This may be because it may be necessary to increase the amount of viral antigen content per virion, rather than the total number of virions, to enhance immunogenicity and cell-mediated immunity. ${ }^{85}$

\section{Adjusting vaccine schedules}

Older adults may mount efficient $\mathrm{T}$ cell responses in response to vaccination, but they are less able to maintain memory responses. ${ }^{86}$ Following pneumococcal polysaccharide vaccine (PPV), not only do the elderly have decreased antibody potency against all serotypes, but there is a steady decline in serotype-specific antibody titers returning to pre-vaccination levels within 5-10 years. ${ }^{87,88}$ In contrast, immune responses generated in youth are long-lasting and protective. An elegant example of this occurred during the H1N1 pandemic when influenza infections in even the oldest and most frail elderly were much lower than expected. Upon investigation, it was found that these individuals had protective antibodies that were generated many decades earlier in response to circulating strains that they were exposed to in youth. ${ }^{89}$ This illustrates that memory responses that are generated in youth are long-lasting and protective well into old age. Consequently, one of the most effective ways to protect the elderly from infections may be to vaccinate them in youth. A robust primary immune response can also lead to more efficient responses to boosters, since it has been shown that pre-vaccination antibody titers dictate the magnitude of booster titers. ${ }^{90}$ Live attenuated vaccines appear to be more efficient at providing increased protection over decades and following booster vaccinations, compared to inactivated vaccines. ${ }^{91}$

\section{Utilization of alternative routes of immunization}

Historically, the preferred approach to vaccine administration has been via percutaneous injection, which includes subcutaneous and intramuscular methods of immunization. However, recent advances in vaccinology and immunotherapeutics have suggested that alternate routes of vaccination may provide superior immunogenicity and protection in elderly populations. ${ }^{92}$ In a large South African study by Holland et al, over 1,100 volunteers over the age of 60 received a trivalent, inactivated influenza vaccine via either intradermal microinjection or intramuscular administration. It was concluded that the intradermal route of vaccination elicited immune responses that were superior, as subjects had higher rates of seroconversion than those who received the conventional intramuscular administration. ${ }^{93}$ Through exploitation of the skin immune system, intradermal vaccination directly delivers antigen to dermal DCs, which efficiently migrate and present antigen to $\mathrm{T}$ cells in draining lymph nodes, thereby naturally augmenting the primary immune response. ${ }^{93}$ In theory, intradermal antigen delivery should allow for a reduction of the antigen dose required to obtain optimal protective responses in the elderly. Two separate studies have shown that using a 2.5-fold decrease in antigen dose, as compared to full-dose vaccines, achieves a suitable response via the intradermal route of vaccination. ${ }^{94,95}$ Despite age-associated changes in skin integrity and physiology, and decreases in Langerhans and DCs, intradermal immunization can elicit protective immune responses in the elderly. ${ }^{96}$

Mucosal vaccination may also be a viable alternative, especially for infections that originate in the upper respiratory tract, such as influenza and pneumonia. ${ }^{97}$ The abundance of APCs in mucosal tissues such as the nasopharynx and gastrointestinal tract facilitate antigen responses. ${ }^{98}$ The nasopharyngeal- and gut-associated lymphoid tissues are reservoirs of immune cells that induce effective antibody production, especially $\operatorname{IgA}$, upon encountering antigen in the context of the appropriate adjuvant. ${ }^{99,100}$ Unlike conventional immunization, antigenic exposure at mucosal sites activates antigen-specific $\mathrm{T}$ cells and $\operatorname{Ig} \mathrm{A}^{+} \mathrm{B}$ cells, which subsequently transit to the lymph, enter the circulation, and seed mucosal sites, primarily the mucosa of origin. ${ }^{99,101,102}$ Upon arrival, mucosal lymphocytes differentiate into effector or memory cells. The anatomic affinity of such cells is determined by surface site-specific integrins (homing receptors) and complementary mucosal tissue-specific receptors. ${ }^{103,104}$ Nasal administration generates both mucosal $\operatorname{IgA}$ and peripheral $\operatorname{IgG}$ responses. IgA antibodies are particularly effective at binding and neutralizing viruses; therefore, mucosal vaccinations should be particularly protective against respiratory infections such as influenza. Currently, only one commercially available mucosal vaccine exists. Intranasal administration of FluMist ${ }^{\circledR}$ has been shown to elicit robust protective responses in adults aged $<49$ years. ${ }^{105}$ However, studies involving patients aged $>50$ years have yet to be conducted; therefore, safe and efficacious use of FluMist in the elderly has not been established. While 
mucosal immunizations demonstrate great potential, there is currently limited research on the development of mucosal vaccines that specifically target the elderly population and overcome the age-associated immune barriers to successful and effective vaccination.

\section{Novel adjuvants that improve immunogenicity}

In contrast to young people, the elderly often do not mount any detectable primary immune response to protein antigens, regardless of dose. In many cases, the commonly used alum adjuvant does not sufficiently increase the immune stimulatory activity of antigens in the elderly. ${ }^{106,107}$ Use of more potent adjuvants may overcome this limitation. One promising candidate is the oil-in-water emulsion adjuvant, MF59тм ${ }^{108}$ Previously, oil emulsion-based adjuvants were associated with side effects such as inflammatory reactions, granulomas, and ulcers at the injection site. ${ }^{109}$ Replacement of mineral oil used in other emulsions with squalene in MF59, however, has limited side effects. ${ }^{110}$ A murine study demonstrated that old mice immunized with an MF59-adjuvanted vaccine produced antibody titers to levels equivalent in young mice. ${ }^{106}$ A similar study demonstrated that MF59 reduced to dose of antigen required, and upon secondary challenge with a wild virus, decreased total viral load and provided significant protection in both young and old mice. ${ }^{107}$ To evaluate MF59 efficacy in humans, multiple clinical studies involving several MF59-adjuvanted vaccines have been performed. Results have demonstrated enhanced immunogenicity in all age groups, while maintaining a high level of safety and tolerability. Being the first adjuvant licensed for human other than alum, MF59 is now part of an influenza vaccine $\left(\right.$ Fluad $\left.^{\circledR}\right)$ designed for the elderly and is readily available worldwide. ${ }^{108,110}$ Though adjuvant activity of MF59 is only partially understood, studies have shown that it induces monocyte recruitment and macrophage trafficking, promotes differentiation of monocytes into DCs, and fosters enhanced antigen uptake by macrophages and DCs. ${ }^{111-113}$ Increased utilization of MF59 in vaccine development, specifically for the elderly population, may serve as a practical solution to enhance immunogenicity.

Other potential immunostimulatory adjuvants, which may enhance immunogenicity in the elderly, include the lipopolysaccharide derivative 3-deacetylated monophosphoryl lipid A, the saponin-derived lipid, QS21, oligodeoxynucleotides containing CpG motifs, and cytokines. ${ }^{114}$ QS21, which is a derivative of the lipid saponin from the bark of the Quillaja saponaria tree, is being tested as an adjuvant in a pneumococcal polysaccharide vaccine (Phase II). ${ }^{114}$ Recently, utilization of toll-like receptor (TLR) agonists as vaccine adjuvants in the elderly has delivered promising results in mouse studies. ${ }^{98,115}$ By targeting evolutionary conserved receptors that recognize pathogens (eg, TLRs or nucleotide-binding oligomerization domain proteins), it is postulated that adjuvants might overcome the age-associated functional decline of innate immune response and induce production of pro-inflammatory cytokines. ${ }^{116} \mathrm{Using}$ TLR agonists as vaccine adjuvants is a method currently in the very early stages of clinical development. In older adults, TLR4 agonists have been shown to improve $\mathrm{T}$ cell response to influenza vaccination. ${ }^{98}$ Additionally, HA-flagellin (TLR5 ligand) fusion proteins (VAX128) were shown to be well-tolerated and safe in aged individuals. ${ }^{117}$ Recently, the use of cytokines in conjunction with vaccines has been explored. IL-7 is important to $\mathrm{T}$ cell survival, and therefore may be useful in maintaining a pool of naïve T cells in the elderly, thus allowing more efficient responses to novel antigens. While to date no studies have been performed in humans, experiments in aged macaques have had promising results, with $50 \%$ of animals demonstrating increased thymic output and restored influenza vaccination response. ${ }^{118}$ Thus, in older adults, IL-7 could potentially be used to amplify vaccine responsiveness. Another potential cytokine candidate would be IL-2, which is well known to increase the number of peripheral T cells in addition to their responsiveness to antigen. Administration of a liposome-formulated vaccine and IL-2 induced significantly higher seroprotection and seroconversion rates against viral antigens as compared to other aged subjects receiving non-adjuvanted vaccine. ${ }^{119}$ Furthermore, combination of coupled adjuvant systems (eg, microparticles which contain both antigen and DNA of a cytokine) may allow for a more targeted immune response in the elderly. ${ }^{120}$

\section{Reversing immunosenescence}

In the near term, novel vaccination strategies will involve working within the confines of the aging immune system; however, in the long term, a number of ambitious strategies are being pursued to correct some of the underlying defects in the aging immune system. Nutritional interventions have been demonstrated to increase vaccine responses in older adults and experimental animals. For example, decreasing specific lipid intake (eg, conjugated linoleic acids) appears to increase vaccine success rates in the elderly. ${ }^{121}$ Vitamin E supplementation improves signaling between antigen-presenting cells and $\mathrm{T}$ cells, especially in $\mathrm{CD}^{+}$-naïve $\mathrm{T}$ cells in aged mice. ${ }^{122}$ Caloric restriction seems to improve many aspects of immune function. It appears to delay $\mathrm{T}$ cell immunosenescence in nonhuman primates by maintaining both naïve $\mathrm{T}$ cell number and functionality, and reduces age-associated inflammation. ${ }^{123}$ 
Although caloric restriction is unlikely to ever be a viable strategy, it may be possible to target the major signaling molecule that is altered, mammalian target of rapamycin (mTOR). A recent study demonstrated that administration of an mTOR inhibitor in elderly volunteers increased their response to influenza vaccination by approximately $20 \%$. Further, treatment reduced the percentage of $\mathrm{CD} 8^{+}$and $\mathrm{CD} 4^{+}$ $\mathrm{T}$ cells that had low surface expression of co-stimulatory molecules. Therefore, mTOR inhibition during vaccination may be a potential strategy. ${ }^{124}$ An alternate strategy would be cytokine intervention to improve thymic health in the elderly. There has been evidence that administration of IL-7 can reverse thymic atrophy and can rescue reduced naïve $\mathrm{T}$ cell population in old animals. ${ }^{125}$ Other factors including IL-2, IL-10, and thymic stromal lymphopoietin have stimulatory effects on thymopoiesis. ${ }^{126,127}$ Restoring thymic health and naïve $\mathrm{T}$ cell populations by modulating these cytokines may be a candidate therapy to increase primary vaccine-specific responses in the elderly.

\section{Optimizing herd immunity}

Counterintuitively, one of the best ways to reduce vaccinepreventable infections in the elderly may be targeting vaccinations, not to the elderly themselves, but to those who live, work, and care for them. Selective vaccination of children, adolescents, and healthcare workers (HCWs) reduces transmission of infections and protects unimmunized and immunocompromised individuals, such as the elderly, through herd immunity. ${ }^{128-130}$ The add-on effects of vaccinating children to protect older adults were apparent after the pneumococcal vaccine was introduced. Not only did the total hospital admissions for IPD in older adults decrease, but the "holiday spikes" that once occurred over the winter holiday season when children were presumed to come in contact with their grandparents, disappeared. ${ }^{131}$ Children and adolescents are major vectors for transmission of infectious diseases because of their high infection rates, prolonged viral shedding with high viral load, and frequent association with other susceptible hosts. ${ }^{132} \mathrm{~A}$ recent study demonstrated that mass influenza vaccination of children (ages 3-6 and ages 7-17 years) with inactivated influenza vaccine lessened influenza-associated morbidity by 2 - to 3.4 -fold in unvaccinated, communitydwelling elderly. ${ }^{133}$

Establishing herd immunity is best achieved through vaccination of the youth and of HCWs, especially those working in close contact with individuals aged $\geq 65$ years. ${ }^{134}$ In a systematic review inclusive of 18 trials assessing the impact of $\mathrm{HCW}$ immunization on vulnerable populations, it was concluded that vaccination of HCWs against influenza provides significant indirect protection to the high-risk individuals. ${ }^{130}$ Additionally, further evidence suggests that $\mathrm{HCW}$ vaccination is associated with substantial decreases in patient mortality. ${ }^{129,130}$ Immunity through further implementation of vaccination programs that preferentially immunize HCWs and children shows promise in protecting our vulnerable elderly.

\section{Conclusion}

Approximately one-third of deaths in the elderly (aged $>65$ years) occur due to infectious disease. ${ }^{135}$ Acquiring infections such as bacterial pneumonia in midlife or late in life often exacerbate or accelerate subclinical or existing chronic inflammatory conditions and can be the harbinger of declining health and decreased quality of life. ${ }^{7,8}$ Therefore, the economic and social costs of infectious disease do not only include the cost of acute care, but also long-term health consequences. Prevention through vaccination would have an enormous impact on reducing the cost of care and improving the quality of life of the elderly. In the immediate term, we need to pursue the use of high-dose vaccines, optimized vaccine schedules, alternate routes of immunization, and novel adjuvants. In the longer term, we may be able to reverse some of the fundamental defects in the aging immune response, which would both increase vaccination responsiveness but also leave the elderly less vulnerable to infectious disease, should they become infected. It is imperative that we expand our understanding of the biological and molecular mechanisms underlying immunosenescence in order to provide older adults with the many years of healthy, independent living that they deserve.

\section{Acknowledgments}

Work in the Bowdish lab is funded by the Canadian Institutes of Health Research (CIHR) and is supported by the McMaster Immunology Research Centre and the MG DeGroote Institute for Infectious Disease Research.

\section{Disclosure}

DMEB is a Canada Research Chair in Aging and Immunity. AN is supported by a CIHR Canada Graduate Scholarship and the Michael Kamin-Hart Memorial Fund. DL is supported by an Early Researcher Award to DMEB.

\section{References}

1. Rehman T. Role of the gut microbiota in age-related chronic inflammation. Endocr Metab Immune Disord Drug Targets. 2012;12: 361-367.

2. Heron M, Tejada-Vera B. Deaths: leading causes for 2005. Natl Vital Stat Rep. 2009;58(8):1-97.

3. Simonsen L, Reichert TA, Viboud C, Blackwelder WC, Taylor RJ, Miller MA. Impact of influenza vaccination on seasonal mortality in the US elderly population. Arch Intern Med. 2005;165(3):265-272. 
4. Centers for Disease Control and Prevention. Estimates of deaths associated with seasonal influenza - United States, 1976-2007. MMWR Morb Mortal Wkly Rep. 2010;59(33):1057-1062

5. National Center for Health Statistics. National Vital Statistics Report. Deaths: Final Data for 2006. Hyattsville, MD: National Center for Health Statistics; 2009.

6. Johnstone J, Eurich DT, Majumdar S, Jin Y, Marrie T. Long-term morbidity and mortality after hospitalization with community-acquired pneumonia: a population-based cohort study. Medicine (Baltimore). 2008;87(6):329-334.

7. Shah FA, Pike F, Alvarez K, et al. Bidirectional relationship between cognitive function and pneumonia. Am J Respir Crit Care Med. 2013;188(5):586-592.

8. Corrales-Medina VF, Alvarez KN, Weissfeld LA, et al. Association between hospitalization for pneumonia and subsequent risk of cardiovascular disease. JAMA. 2015;313(3):264-274.

9. Saliba W, Fediai A, Edelstein H, Markel A, Raz R. Trends in the burden of infectious disease hospitalizations among the elderly in the last decade. Eur J Intern Med. 2013;24(6):536-540.

10. Public Health Agency of Canada [homepage on the Internet]. Canadian Immunization Guide. National Advisory Committee on Immunization; 2013 [updated June 22, 2015]. Available from: http://www.phac-aspc. gc.ca/publicat/cig-gci/p01-14-eng.php. Accessed August 27, 2013.

11. Goronzy JJ, Weyand CM. Understanding immunosenescence to improve responses to vaccines. Nat Immunol. 2013;4(5):428-436.

12. Lang P, Mendes A, Socquet J, Assir N, Govind S, Aspinall R. Effectiveness of influenza vaccine in aging and older adults: comprehensive analysis of the evidence. Clin Interv Aging. 2012;7:55-64.

13. Williams WW, Lu PJ, O'Halloran A, et al; Centers for Disease Control and Prevention. Noninfluenza vaccination coverage among adults United States, 2012. MMWR Morb Mortal Wkly Rep. 2014;63(5): 95-102.

14. Jefferson T, Di Pietrantonj C, Al-Ansary LA, Ferroni E, Thorning S, Thomas RE. Vaccines for preventing influenza in the elderly [review]. Cochrane Database Syst Rev. 2010;2:CD004876.

15. Jefferson T, Rivetti D, Rivetti A, Rudin M, Di Pietrantonj C, Demicheli V. Efficacy and effectiveness of influenza vaccines in elderly people: a systematic review. Lancet. 2005;366:1165-1174.

16. Metersky M, Masterton R, Lode H, File T, Babinchak T. Epidemiology, microbiology, and treatment considerations for bacterial pneumonia complicating influenza. Int J Infect Dis. 2012;16(5):e321-e331.

17. Moberley SA, Holden J, Tatham DP, Andrews RM. Vaccines for preventing pneumococcal infection in adults [review]. Cochrane Database Syst Rev. 2008;1:CD000422.

18. Ochoa-Gondar O, Vila-Corcoles A, Rodriguez-Blanco T, et al. Effectiveness of the 23-valent pneumococcal polysaccharide vaccine against community-acquired pneumonia in the general population aged $\geq 60$ years: 3 years of follow-up in the CAPAMIS study. Clin Infect Dis. 2014;58(7):909-917.

19. Rudnick W, Liu Z, Shigayeva A, et al; Toronto Invasive Bacterial Diseases Network. Pneumococcal vaccination programs and the burden of invasive pneumococcal disease in Ontario, Canada, 1995-2011. Vaccine. 2013;31(49):5863-5871.

20. Leventer-Roberts M, Feldman BS, Brufman I, Cohen-Stavi CJ, Hosen M, Balicer RD. Effectiveness of 23-valent pneumococcal polysaccharide vaccine against invasive disease and hospital-treated pneumonia among people aged 65+: a retrospective case-control study. Clin Infect Dis. 2015;60(10):1472-1480.

21. Huss A, Scott P, Stuck AE, Trotter C, Egger M. Efficacy of pneumococcal vaccination in adults: a meta-analysis. CMAJ. 2009;180(1):48-58.

22. Franceschi C, Capri M, Monti D, et al. Inflammaging and antiinflammaging: a systemic perspective on aging and longevity emerged from studies in humans. Mech Ageing Dev. 2007;128(1): 92-105.

23. Hoebe K, Janssen E, Beutler B. The interface between innate and adaptive immunity. Nat Immunol. 2004;5:971-974.
24. Barton GM, Medzhitov R. Toll-like receptors and their ligands. Curr Top Microbiol Immunol. 2002;270:81-92.

25. Iwasaki A, Medzhitov R. Toll-like receptor control of the adaptive immune responses. Nat Immunol. 2004;5:987-995.

26. Fox C, Kramer RM, Barnes VL, Dowling QM, Vedvick TS. Working together: interactions between vaccine antigens and adjuvants. Ther Adv Vaccines. 2013;1(1):7-20.

27. Arepanris ${ }^{\mathrm{TM}}(\mathrm{H} 1 \mathrm{~N} 1 \mathrm{AS} 03$-adjuvanted H1N1 pandemic influenza vaccine) [package insert]. GlaxoSmithKline; 2010.

28. Hugues S, Boissonnas A, Amigorena S, Fetler L. The dynamics of dendritic cell-T cell interactions in priming and tolerance. Curr Opin Immunol. 2006;18:491-495.

29. Kapsenberg ML. Dendritic-cell control of pathogen-driven T-cell polarization. Nat Rev Immunol. 2003;3:984-993.

30. Siegrist CA. Vaccine immunology. In: Plotkin SA, Orenstein WA, and Offit PA, editors. Vaccines. 5th ed. Amsterdam: Elsevier Press; 2008:17-36.

31. Weintraub A. Immunology of bacterial polysaccharide antigens. Carbohydr Res. 2003;338:2539-2547.

32. Zhou J, Lottenbach KR, Barenkamp SJ, Reason DC. Somatic hypermutation and diverse immunoglobulin gene usage in the human antibody response to the capsular polysaccharide of Streptococcus pneumoniae Type 6B. Infect Immun. 2005;72:3505-3514.

33. Shapiro-Shelef M, Calame K. Regulation of plasma-cell development. Nat Rev Immunol. 2005;5(3):230-242.

34. Huehn J, Siegmund K, Hamann A. Migration rules: functional properties of I and effector/memory-like regulatory T cell subsets. Curr Top Microbiol Immunol. 2005;293:89-114.

35. Chua JV, Chen WH. Herpes zoster vaccine for the elderly: boosting immunity. Aging Health. 2010;6:169-176.

36. Levin MJ, Oxman MN, Zhang JH, et al; Veterans Affairs Cooperative Studies Program Shingles Prevention Study Investigators. Varicellazoster virus-specific immune responses in elderly recipients of a herpes zoster vaccine. J Infect Dis. 2008;197:825-835.

37. Schenkein JG, Park S, Nahm MH. Pneumococcal vaccination in older adults induces antibodies with low opsonic capacity and reduced antibody potency. Vaccine. 2008;26(43):5521-5526.

38. Fedson DS, Musher DM. Pneumococcal polysaccharide vaccine. In: Plotkin SA, Orenstein WA, editors. Vaccines. Philadelphia: Saunders; 2003:529-588.

39. Grewe M. Chronological ageing and photoageing of dendritic cells. Clin Exp Dermatol. 2001;26:608-612.

40. van Duin D, Shaw AC. Toll-like receptors in older adults. J Am Geriatr Soc. 2007;55:1438-1444.

41. Davila DR, Edwards CK 3rd, Arkins S, Simon J, Kelley KW. Interferongamma-induced priming for secretion of superoxide anion and tumor necrosis factor-alpha declines in macrophages from aged rats. FASEB J. 1990;4(11):2906-2911.

42. Tasat DR, Mancuso R, O’Connor S, Molinari B. Age-dependent changes in reactive oxygen species and nitric oxide generation by rat alveolar macrophages. Aging Cell. 2003;2:159-164.

43. Kissin E, Tomasi M, McCartney-Francis N, Gibbs CL, Smith PD. Age-related decline in murine macrophage production of nitric oxide. J Infect Dis. 1997;175:1004-1007.

44. Agrawal A, Agrawal S, Gupta S. Dendritic cells in human aging. Exp Gerontol. 2007;42(5):421-426.

45. Renshaw M, Rockwell J, Engleman C, Gewirtz A, Katz J, Sambhara S. Cutting edge: impaired Toll-like receptor expression and function in aging. J Immunol. 2002;169(9):4697-4701.

46. Panda A, Qian F, Mohanty S, et al. Age-associated decrease in TLR function in primary human dendritic cells predicts influenza vaccine response. J Immunol. 2010;184(5):2518- 2527.

47. Cao W, Kim JH, Chirkova T, et al. Improving immunogenicity and effectiveness of influenza vaccine in older adults. Expert Rev Vaccines. 2011;10(11):1529-1537. 
48. Linton PJ, Dorshkind K. Age-related changes in lymphocyte development and function. Nat Immunol. 2004;5:133-139.

49. Cambier J. Immunosenescence: a problem of lymphopoiesis, homeostasis, microenvironment and signaling. Immunol Rev. 2005;205:5-6.

50. Weinberger B, Herndler-Brandstetter D, Schwanninger A, Weiskopf D, Grubeck-Loebenstein B. Biology of immune responses to vaccines in elderly persons. Clin Infect Dis. 2008;46(7):1078-1084.

51. Lelic A, Verschoor CP, Ventresca M, et al. The polyfunctionality of human memory CD8+ T cells elicited by acute and chronic virus infections is not influenced by age. PloS Pathog. 2012;8(12):e1003076.

52. Han S, Yang K, Ozen Z, et al. Enhanced differentiation of splenic plasma cells but diminished long-lived high-affinity bone marrow plasma cells in aged mice. J Immunol. 2003;170:1267-1273.

53. Haynes L, Eaton SM. The effect of age on the cognate function of CD4+ T cells. Immunol Rev. 2005;205:220-228.

54. Frasca D, Riley RL, Blomberg BB. Humoral immune response and B-cell functions including immunoglobulin class switch are downregulated in aged mice and humans. Semin Immunol. 2005;17:378-384.

55. Labrie JE 3rd, Sah AP, Allman DM, Cancro MP, Gerstein RM. Bone marrow microenvironmental changes underlie reduced RAG-mediated recombination and B cell generation in aged mice. J Exp Med. 2004;200: 411-423.

56. Steinmann GG, Klaus B, Müller-Hermelink HK. The involution of the ageing human thymic epithelium is independent of puberty: a morphometric study. Scand J Immunol. 1985;22:563-575.

57. Lazuardi L, Jenewein B, Wolf AM, Pfister G, Tzankov A, GrubeckLoebenstein B. Age-related loss of naïve T cells and dysregulation of T-cell/B-cell interactions in human lymph nodes. Immunology. 2005;114:37-43.

58. Haynes L, Linton, PJ, Eaton SM, Tonkonogy SL, Swain SL. Interleukin 2, but not other common gamma chain-binding cytokines, can reverse the defect in generation of CD4 effector T cells from IT cells of aged mice. J Exp Med. 1999;190:1013-1024.

59. Eaton SM, Burns EM, Kusser K, Randall TD, Haynes L. Age-related defects in CD4 $\mathrm{T}$ cell cognate helper function lead to reductions in humoral responses. J Exp Med. 2004;200:1613-1622.

60. Haynes L, Eaton SM, Burns EM, Randall TD, Swain SL. CD4 T cell memory derived from young I cells functions well into old age, but memory generated from aged I cells functions poorly. Proc Natl Acad Sci U S A. 2003;100(25):15053-15058.

61. Decman V, Laidlaw BJ, Doering TA, et al. Defective CD8 T cell responses in aged mice are due to quantitative and qualitative changes in virus-specific precursors. J. Immunol. 2012;188:1933-1941.

62. Cicin-Sain L, Smyk-Pearson S, Currier N, et al. Loss of I T cells and repertoire constriction predict poor response to vaccination in old primates. J Immunol. 2010;184:6739-6745.

63. Khan N, Hislop A, Gudgeon N, et al. Herpesvirus-specific CD8 T cell immunity in old age: cytomegalovirus impairs the response to a coresident EBV infection. J Immunol. 2004;173:7481-7489.

64. Goronzy JJ, Fulbright JW, Crowson CS, Poland GA, O'Fallon WM, Weyand $\mathrm{CM}$. Value of immunological markers in predicting responsiveness to influenza vaccination in elderly individuals. JVirol. 2001;75(24): 12182-12187.

65. Saurwein-Teissl M, Lung TL, Marx F, et al. Lack of antibody production following immunization in old age: association with (+)CD28(-) T cell clonal expansions and an imbalance in the production of Th1 and Th2 cytokines. J. Immunol. 2002;168:5893-5899.

66. Almanzar G, Schwaiger S, Jenewein B, et al. Long-term cytomegalovirus infection leads to significant changes in the composition of the CD8+ T-cell repertoire, which may be the basis for an imbalance in the cytokine production profile in elderly persons. J Virol. 2005;79(6): 3675-3683.

67. Trzonkowski P, Myśliwska J, Szmit E, et al. Association between cytomegalovirus infection, enhanced proinflammatory response and low level of anti-hemagglutinins during the anti-influenza vaccination - an impact of immunosenescence. Vaccine. 2003;21(25-26):3826-3836.
68. Gao HM, Hong JS. Why neurodegenerative diseases are progressive: uncontrolled inflammation drives disease progression. Trends Immunol. 2008;29(8):357-365.

69. Libby P. Inflammation in atherosclerosis. Arterioscler Thromb Vasc Biol. 2012;32(9):2045-2051.

70. Yendes S, Tuomanen EI, Winderink R, et al. Preinfection systemic inflammatory markers and risk of hospitalization due to pneumonia. Am J Respir Crit Care Med. 2005;172(11):1440-1446.

71. Shaw AC, Goldstein DR, Montgomery RR. Age-dependent dysregulation of innate immunity. Nat Rev Immunol. 2013;13:875-887.

72. Grubeck-Loebenstein B, Della Bella S, Iorio AM, Michel JP, Pawelec G, Solana R. Immunosenescence and vaccine failure in the elderly. Aging Clin Exp Res. 2009;21(3):201-209.

73. Song X, Mitnitski A, Rockwood K. Prevalence and 10-year outcomes of frailty in older adults in relation to deficit accumulation. J Am Geriatr Soc. 2010;58(4):681-687.

74. Yao X, Hamilton RG, Weng N, et al. Frailty is associated with impairment of vaccine-induced antibody response and increase in postvaccination influenza infection in community-dwelling older adults. Vaccine. 2011;29(31):5015-5021.

75. Mitnitski AB, Mogilner AJ, Rockwood K. Accumulation of deficits as a proxy measure of aging. ScientificWorldJournal. 2001;1: 323-336.

76. Searle SD, Mitnitski A, Gahbauer EA, Gill TM, Rockwood K. A standard procedure for creating a frailty index. BMC Geriatr. 2008;8:24.

77. Li H, Manwani B, Leng SX. Frailty, inflammation, and immunity. Aging Dis. 2011;2(6):466-473

78. Visser M, Pahor M, Taaffe DR, et al. Relationship of interleukin-6 and tumor necrosis factor-alpha with muscle mass and muscle strength in elderly men and women: The Health ABC Study. J Gerontol A Biol Sci Med Sci. 2002;57(5):M326-M332.

79. Harris TB, Ferrucci L, Tracy RP, et al. Associations of elevated interleukin-6 and C-reactive protein levels with mortality in the elderly. $\mathrm{Am}$ J Med. 1999;106(5):506-512.

80. Ligthart GJ, Corberand JX, Geertzen HG, Meinders AE, Knook DL, Hijmans W. Necessity of the assessment of health status in human immunogerontological studies: evaluation of the SENIEUR protocol. Mech Ageing Dev. 1990;55(1):89-105.

81. Keitel W, Atmar R, Cate T, et al. Safety of high doses of influenza vaccine and effect on antibody responses in elderly persons. Arch Intern Med. 2006;166(10):1121-1127.

82. Falsey A, Treanor JJ, Tornieporth N, Capellan J, Gorse GJ. Randomized, double-blind controlled phase 3 trial comparing the immunogenicity of high-dose and standard-dose influenza vaccine in adults 65 years of age and older. J Infect Dis. 2009;200(2):172-180.

83. Roos-Van Eijndhoven DG, Cools HJ, Westendorp RG, Ten Cate-Hoek AJ, Knook DL, Remarque EJ. Randomized controlled trial of seroresponses to double dose and booster influenza vaccination in frail elderly subjects. J Med Virol. 2001;63:293-298.

84. Trannoy E, Berger R, Holländer G, Bailleux F, Heimendinger P, Vuillier D, Creusvaux H. Vaccination of immunocompetent elderly subjects with a live attenuated Oka strain of varicella zoster virus: a randomized, controlled, dose-response trial. Vaccine. 2000;18:1700-1706.

85. Bergen RE, Diaz PS, Arvin AM. The immunogenicity of the Oka/ Merck varicella vaccine in relation to infectious varicella-zoster virus and relative viral antigen content. J Infect Dis. 1990;162:1049-1054.

86. Kang I, Hong MS, Nolasco H, et al. Age-associated change in the frequency of memory CD4+ T cells impairs long term CD4+ T cell responses to influenza vaccine. J Immunol. 2004;173:673-681.

87. Schenkein JG, Park S, Nahm MH. Pneumococcal vaccination in older adults induces antibodies with low opsonic capacity and reduced antibody potency. Vaccine. 2008;26(43):5521-5526.

88. Fedson DS, Musher DM. Pneumococcal polysaccharide vaccine. In: Plotkin SA, Orenstein WA, editors. Vaccines. Philadelphia: Saunders; 2003:529-588. 
89. Ikonen N, Strengell M, Kinnunen L, et al. High frequency of crossreacting antibodies against 2009 pandemic influenza $\mathrm{A}(\mathrm{H} 1 \mathrm{N1})$ virus among the elderly in Finland. Euro Surveill. 2010;15(5):19478.

90. Kaml M, Weiskirchner I, Keller M, et al. Booster vaccination in the elderly: their success depends on the vaccine type applied earlier in life as well as on pre-vaccination antibody titers. Vaccine. 2006;24: 6808-6811.

91. Cox RJ, Brokstad KA, Ogra P. Influenza virus: immunity and vaccination strategies. Comparison of the immune response to inactivated and live, attenuated influenza vaccines. Scand J Immunol. 2004;59: $1-15$.

92. Bellanti JA, Zeligs BJ, Mendez de Inocencio J, Omidvar BM, Omidvar J, Awasum M. Alternative routes of immunization for prevention of infectious diseases: a new paradigm for the 21 st century. Allergy Asthma Proc. 2011;22(3):173-176.

93. Holland D, Booy R, De Looze F, et al. Intradermal influenza vaccine administered using a new microinjection system produces superior immunogenicity in elderly adults: a randomized controlled trial. J Infect Dis. 2008;198(5):650-658.

94. Belshe RB, Newman FK, Cannon J, et al. Serum antibody responses after intradermal vaccination against influenza. $N$ Engl J Med. 2004;351:2286-2294.

95. Kenney RT, Frech SA, Muenz LR, Villar CP, Glenn GM. Dose sparing with intradermal injection of influenza vaccine. $N$ Engl J Med. 2004;351:2295-2301.

96. Panda A, Arjona A, Sapey E, et al. Human innate immunosenescence: causes and consequences for immunity in old age. Trends Immunol. 2009;30:325-333.

97. Corrigan EM, Clancy RL. Is there a role for a mucosal influenza vaccine in the elderly? Drugs Aging. 1999;15(3):169-181.

98. Behzad H, Huckriede AL, Haynes L, et al. GLA-SE, a synthetic tolllike receptor 4 agonist, enhances T-cell responses to influenza vaccine in older adults. $J$ Infect Dis. 2012;205(3):466-473.

99. Kuper CF, Koornstra PJ, Hameleers DM, et al. The role of nasopharyngeal lymphoid tissues. Immunol Today. 1992;13:219-224.

100. Brandtzaeg P. Basic mechanisms of mucosal immunity - a major adaptive defense system. Immunologist. 1995;3:89-96.

101. McGhee JR, Kiyono H. Mucosal Immunology. Fundamental Immunology. Waltham, MA: Academic Press; 1998

102. McGhee JR, Kiyono H. New perspectives in vaccine development: mucosal immunity to infections. Infect Agents Dis. 1993;2:55-73.

103. Kunkel EJ, Butcher EC. Plasma-cell homing. Nat Rev Immunol. 2003;3:822-829.

104. Holmgren J, Czerkinsky C. Mucosal immunity and vaccines. Nat Med. 2005;11:S45-S53.

105. Carter NJ, Curran MP. Live attenuated influenza vaccine (FluMist ${ }^{\mathbb{R}}$; Fluenz $\left.{ }^{\mathrm{TM}}\right)$ : a review of its use in the prevention of seasonal influenza in children and adults. Drugs. 2011;71(12):1591-1622.

106. Higgins DA, Carlson JR, van Nest G. MF59 enhances the immunogenicity of influenza vaccine in both young and old mice. Vaccine. 1996; $14: 478-484$.

107. Cataldo DM, Van Nest G. The adjuvant MF59 increases the immunogenicity and protective efficacy of subunit influenza vaccine in mice. Vaccine, 1997;15:1710-1715.

108. Podda A, Del Giudice G. MF59-adjuvanted vaccines: increased immunogenicity with an optimal safety profile. Expert Rev Vaccines. 2003;2(2):197-203.

109. Petrovsky N, Aguilar JC. Vaccine adjuvants: current state and future trends. Immunol Cell Biol. 2004;82:488-496.

110. Podda A, Del Giudice G, O’Hagan DT. MF59: a safe and potent adjuvant for human use. In: Schijns V, O’Hagan DT, editors. Immunopotentiators in Modern Medicines. Amsterdam: Elsevier Press; 2005.

111. Dupuis M, Denis-Mize K, LaBarbara A, et al. Immunization with the adjuvant MF59 induces macrophage trafficking and apoptosis. Eur J Immunol. 2001;31:2910-2918.
112. Seubert A, Monaci E, Pizza M, O’Hagan DT, Wack A. The adjuvants aluminum hydroxide and MF59 induce monocyte and granulocyte chemoattractants and enhance monocyte differentiation toward dendritic cells. J Immunol. 2008;180:5402-5412.

113. Mosca F, Tritto E, Muzzi A, et al. Molecular and cellular signatures of human vaccine adjuvants. Proc Natl Acad Sci U S A. 2008;105: 10501-10506

114. Kovaiou RD, Herndler-Brandstetter D, Grubeck-Loebenstein B. Age-related changes in immunity: implications for vaccination in the elderly. Expert Rev Mol Med. 2007;9(3):1-17.

115. Schreibelt G, Benitez-Ribas D, Schuurhuis D, et al. Commonly used prophylactic vaccines as an alternative for synthetically produced TLR ligands to mature monocyte-derived dendritic cells. Blood. 2010;116: 564-574.

116. Herndler-Brandsetter D, Cioca DP, Grubeck-Loebenstein B. Immunizations in the elderly: do they live up to their promise? Wien Med Wochenschr. 2006;156:130-141.

117. Taylor DN, Treanor JJ, Sheldon EA, et al. Development of VAX128, a recombinant hemagglutinin (HA) influenza-flagellin fusion vaccine with improved safety and immune response. Vaccine. 2012;30: 5761-5769.

118. Aspinall R, Pido-Lopez J, Imami N, et al. Old rhesus macaques treated with interleukin-7 show increased TREC levels and respond well to influenza vaccination. Rejuvenation Res. 2007;10:5-17.

119. Ben-Yehuda A, Joseph A, Zeira E, et al. Immunogenicity and safety of a novel liposomal influenza subunit vaccine (INFLUSOME-VAC) in young adults. J Med Virol. 2003;69:560-567.

120. Levine MM, Sztein MB. Vaccine development strategies for improving immunization: the role of modern immunology. Nat Immunol. 2004;5(5):460-464.

121. Albers R, van der Wielen RP, Brink EJ, Hendriks HF, Dorovska-Taran VN, Mohede IC. Effects of cis-9, trans-11 and trans-10, cis-12 conjugated linoleic acid (CLA) isomers on immune function in healthy men. Eur J Clin Nutr. 2003;57:595-603.

122. Marko MG, Ahmed T, Bunnell SC, et al. Age-associated decline in effective immune synapse formation of CD4(+) T cells is reversed by vitamin E supplementation. J Immunol. 2007;178:1443-1449.

123. Messaoudi I, Warner J, Fischer M, et al. Delay of T cell senescence by caloric restriction in aged long-lived nonhuman primates. Proc Natl Acad Sci US A. 2006;103:19448-19453.

124. Mannick JB, Del Giudice G, Lattanzi M, et al. mTOR inhibition improves immune function in the elderly. Sci Transl Med. 2014; 6(268):268ra179.

125. Andrew D, Aspinall R. IL-7 and not stem cell factor reverses both the increase in apoptosis and the decline in thymopoiesis seen in aged mice. J Immunol. 2001;166:1524-1530.

126. Ongrádi J, Stercz B, Kövesdi V, Vértes L. Immunosenescence and vaccination of the elderly II. New strategies to restore age-related immune impairment. Acta Microbiol Immunol Hung. 2009;56(4):301-312.

127. Foy TM, Aruffo A, Bajorath J, Buhlmann JE, Noelle RJ. Immune regulation by CD40 and its ligand GP39. Annu Rev Immunol. 1996;14: 591-617.

128. Loeb M, Russell ML, Moss L, et al. Effect of influenza vaccination of children on infection rates in Hutterite communities: a randomized trial. JAMA. 2010;303(10):943-950.

129. Carman WF, Elder AG, Wallace LA, et al. Effects of influenza vaccination of health-care workers on mortality of elderly people in long-term care: a andomized controlled trial. Lancet. 2000;355(9198):93-97.

130. Burls A, Jordan R, Barton P, et al. Vaccinating healthcare workers against influenza to protect the vulnerable - is it a good use of healthcare resources? A systematic review of the evidence and an economic evaluation. Vaccine. 2006;24(19): 4212-4221.

131. Walter ND, Taylor TH Jr, Dowel SF, Mathis S, Moore MR; Active Bacterial Core Surveillance System Team. Holiday spikes in pneumococcal disease among older adults. N Engl J Med. 2009;361: 2584-2585. 
132. Longini IM Jr, Koopman JS, Monto AS, Fox JP. Estimating household and community transmission parameters for influenza. Am J Epidemiol. 1982;115(5):736-751.

133. Ghendon YZ, Kaira AN, Elshina GA. The effect of mass influenza immunization in children on the morbidity of the unvaccinated elderly. Epidemiol Infect. 2006;134(1):71-78.
134. Lang PO, Aspinall R. Immunosenescence and herd immunity: with an ever-increasing aging population do we need to rethink vaccine schedules? Expert Rev Vaccines. 2012;11(2):167-176.

135. Mouton CP, Bazaldua OV, Pierce B, Espino DV. Common infections in older adults. Health Care Food Nutr Focus. 2001;8(3):1, 3-7.

\section{Publish your work in this journal}

Vaccine: Development and Therapy is an international, peer-reviewed, open access journal that spans the spectrum of vaccine design and development through to clinical applications. The journal is characterized by the rapid reporting of application notes, reviews, original research and clinical studies in all therapeutic areas. Clinical outcomes, patient safety, and programs for the development and effective, safe, and sustained use of vaccines will be a feature of the journal. The manuscript management system is completely online and includes a very quick and fair peer-review system. Visit http://www.dovepress.com/testimonials.php to read real quotes from published authors.

Submit your manuscript here: http://www.dovepress.com/vaccine-development-and-therapy-journal 